\title{
A Corpus-Based Analysis of the Most Frequent Idiomatic Expressions: The Semantic Differences Between British and American Idioms in LID
}

Salih Mahdi Adai Al-Mamoory, English Department, College of Education for Human Sciences, Babylon University,Iraq, salih_mehdi71@yahoo.com

Abdul-Haq Abdul-Kareem Abdullah Al-Sahlani, English Department, College of Education for Human Sciences, Babylon University, Iraq, s.savu77@yahoo.com

Abstract. The present study is concerned with the semantic variations between British and American idiomatic expressions. The semantic distinction aims at showing that recognizing British and American idioms is an essential criterion in studying English idioms. It is hypothesized that: idiomatic expressions pose situational differences owing to the repeated use of idioms in additional contexts. The special use of idioms results in semantic variations between idioms in both varieties of English.

In order to achieve the aims of this paper and test its hypothesis, Halliday and Hasan (1985) analyse texts with reference to the cultural background of language-users. That is to say, a text, which is a form of language in actual use, makes the right sense according to all the surroundings of that text. Besides, finding out the way in which idioms occur in specific situations, Firth's (1950) linguistic theory is further used to detect the importance of how idioms are actually used in real life situations that distinguish between British and American English idioms.

Keywords: Idioms, Corpus, WordSmith Tools \& Semantic Change. Received: 04.12.2020 Accepted: 20.01.2021

Published: 03.02.2021

\section{INTRODUCTION}

The term idiom refers to any sequence of words, usually having a meaning other than the total meanings of the composing words. Idiomatic expressions normally permit little or no semantic and/or syntactic variability. That is, an idiom is a fixed expression which is likely to cause a problem for learners of English. Mastering idioms is a key criterion in determining the mastery of English.

However, when dealing with language varieties, one will encounter certain differences that may cause communicative problems. Thus, when investigating British and American idioms one is likely to find these differences and what characterizes them. Moreover, cultural differences contribute greatly to the divergence of idioms. Such divergence is enhanced through the passage of time and geographical distance.

This study, however, aims at showing the semantic differences between British and American idioms by trying to answer the following questions:

1. Which variety is more idiomatic? And does such a characteristic affect language change?

2. What semantic variations do British and American idioms pose?

3. What are the main social tendencies for generating idioms in the two varieties?

\section{LITERATURE REVIEW}

\section{The Notion of Idioms}

The term idiom comes from the Greek word idioma, which means (specific property, special phrasing); it also comes from idios, (one's own, personal, private). The term relates to the archaic idiotism. All these terms specifically mean the following:

1. The speech proper to, or typical of, a people or place; a dialect or local language; the unique quality or genius of a language.

2. An expression unique to a language, especially one whose sense is not predictable from the meanings and arrangement of its elements. (Alber, 2013: 7). 
In specifying the term idiom, Crystal (2019: 515) says that it is a term used in grammar and lexicology to indicate the sequence of words which functions as a single unit, due to its semantic and syntactic restrictions. The meaning of an idiom is not deducible from the meanings of the individual composing words. In idioms, words do not allow the variability they show in other contexts, e.g.

- It's raining cats and dogs.

Does not allow, for example:

- It's raining a cat and a dog/dogs and cats.

This is caused by their lack of internal contrastivity. Idioms are sometimes labelled as ready-made utterances or as habitual collocations (ibid.).

Zerfas (2014: 4) defines idiom as a grammatical sequence of words approved by the usage of a language, or as a special phraseology. Both the sequence and the special phraseology are peculiar to a language and have a meaning other than its grammatical or logical one.

According to Baugh (1957: 12), these expressions create a difficulty faced by non-native speakers when trying to express themselves not only logically but also idiomatically. A foreigner who has learned the English idiom:

- To press a person to do something.

makes a natural mistake when he/she says:

- *We cannot squeeze the young lady to sing!

The replacement of press for squeeze is in a way logical but not idiomatic (ibid.).

\section{The Importance of Idioms}

Whitford and Dixson (1973: I) say that when dealing with English and having some experience in it, one is liable to recognise the importance of idioms, which introduce and add colour, grace and exactness to speech and writing. Students of English as a foreign language lack confidence in their ability to use idiomatic expressions. Even those fluent in English are often puzzled by the idiomatic structure of the language. Moreover, if students do not use idioms, their speech and writing tend to become formal and unnatural. The two linguists further say that:

Students of language are no doubt aware of the different words used to describe similar things in Britain and the U.S., such as British Petrol for American gasoline, cinema for movie, lift for elevator, etc. In the case of idiomatic usage, the difference is even greater and much more subtle. (ibid.)

However, idioms carry certain thoughts. Knowing the thought carried by the idiom is a very important step in using that idiom. These thoughts are the core of the idiom. They can exploit many idioms, conveying the same thought, but used in different situations. Ideas activate the generation of idioms. In Longman Idioms Dictionary (1998), these ideas are called concept words, e.g. under the concept word problem there is a group called having problems, another group is called cause problem for somebody, and so forth. Categorising idioms in such groups, each having its own concept word, can reveal the similarities and differences between idioms according to a semantic basis, it can also ease the process of learning idioms.

\section{Viewpoints on Idioms}

Clark and Clark (1977: 443, 446) and Fernando and Flavell (1981: 23-24) stress that idiomatic expressions are not readily caught by the mind because they are the petrified remains of dead metaphors. For instance, kick the bucket may have suggested a vivid metaphor for dying. This idiom is originally taken from the method of killing pigs in Norfolk, England. A pig, which was about to be killed, had a bucket under it so that blood could be drained into the bucket. The nervous reflex actions of the pig, after cutting its throat, would cause the pig to kick- the bucket by its hind feet. Nevertheless, this metaphor has since become so petrified that it is no more recognisable.

From a semantic viewpoint, idiom is like a single word, but it does not function like one. Fromkin and Rodman (1988: 23) believe that this is because of the need for the grammatical variability so that languageusers could cope with these expressions. Thus, the past tense of:

- $\quad$ Kick the bucket.

is not:

- *Kick the bucketed.

On the contrary, it, to a certain extent, functions like a normal sequence of grammatical words, so the past tense is: 
- $\quad$ kicked the bucket. (ibid.)

Nonetheless, Fromkin and Rodman (ibid: 23) add that there are many restrictions. A great deal of idioms contain a verb and a noun, although the verb may be placed in the past tense, the number of the noun can never be changed, as in:

- Spilled the beans *Spilled the bean

- Fly off the handle *Fly off the handles

- Kick the bucket *Kick the buckets

(ibid.)

\section{Ready-made Idioms}

Following Fromkin and Rodman's (1988: 23) perspective on idioms, idioms are frozen and ready-made utterances but there are some idioms, which permit a degree of internal change, and are more literal in meaning than others. Hence, the semantic and syntactic frozenness allows only a small number of idioms to experience any internal change, e. g.

- The FBI kept tabs on radicals. (Am.)

- Tabs were kept on radicals by the FBI. (Am.)

- $\quad$ Radicals were kept tabs on by the FBI. (Am.)

(ibid.)

Idioms, in the view of Fromkin and Rodman (ibid.: 237-238), can break the rules on combining semantic properties. The object of eat, for example, must usually be something related to the semantic property edible, but the following idiom violates this restriction:

- He ate his hat. (ibid.)

For this reason, idioms should be entered in the mental lexicon as single items with their specified meaning. Recognising idioms as single items reveals an essential fact about most idioms in that they can readily be identified with the familiar parts of speech. Makkai (1975: V) believes that some idioms are noticeably verbal in nature like get away with, get up, work out, turn in, etc. A large number of idioms are nominal in nature, hence hotdog, Whitehouse, etc. are nouns. Many idioms are adjectives, e.g.

- Pepper and salt (=grey). (ibid.)

many others are adverbials e.g.

- $\quad$ Like the breeze (=easily).

- Hammer and tongs (=violently). (ibid.)

Therefore, the idioms, which correlate with the familiar parts of speech, are called lexemic idioms.

\section{The Range of Idioms}

It may be important to mention what the range of idioms is, in order to have some idea about the nature of idiom generation and what is felt about idioms in their various details. Idioms, however, are categorized, by Cowie et al. (1983: xii-xiii) and Fernando and Flavell (1981: 28), into three major groups. This is done to reveal certain facts about the continuum of meaning from totally transparent to the totally opaque. The groups are as follows:

\section{Restricted Collocations}

In these combinations, if comprising two words, one word has a figurative sense not found outside that limited context. The other word appears in a familiar, literal sense as in:

- Jog one's memory.

- A blind alley.

(Oxford Dictionary of Current Idiomatic English, henceforth ODCIE, 1983)

Some members of this category allow a degree of lexical variation, e.g.

- A cardinal error/sin/virtue/grace. ODCIE (1983)

For the last example, restricted collocations are just like the ordinary open collocations. Another point of similarity is that the literal element is sometimes replaced by a pronoun, or deleted where there is an earlier use of the full expression:

- The Board didn't entertain the idea, and the Senate wouldn't entertain it either. Fernando and Flavell (1981)

- Bloggs had a rather chequered career, and I've heard it said that Blenkinsop's was equally chequered (or: an equally chequered one). (Ibid.) 


\section{Figurative Idioms}

This category is idiomatic to the extent that any variation is rarely found, and pronoun substitution is unlikely, but exclude the following:

- The boot/shoe is on the other foot.

- A close/narrow shave.

- Bill had a narrow shave and Fred an even narrower one.

ODCIE (1983)

There is no clear dividing boundary between figurative idioms, also known as semi-opaque expressions, and pure idioms. Some examples shed light on the last idea, e.g.

- Beat one's breast.

- Burn one's boats. ODCIE (1983)

The literal meaning of these expressions does not compete with their figurative meaning. Some speakers believe that the two meanings are unrelated, for such speakers figurative idioms are part of pure idioms.

\section{Pure Idioms}

These expressions are considered highly idiomatic. Historically, they form the last stage of a process by which word-combinations get to be first established through constant reuse, then they undergo figurative extension and finally petrify. These congealed word-groupings are also called opaque expressions depending on the difficulty of extracting meaning from them.

As for the two accompanying features of idioms, i.e. non-literalness and opacity, Fernando (1996: 65) distinguishes between these two features on the grounds that opacity is subject to the language-user. Opacity, therefore, is more likely to be considered an incidental feature of pure or semi-idioms. On the other hand, though not all idioms are non-literal such as:

- $\quad$ Tall, dark and handsome. (ibid.)

Non-literalness is an intrinsic feature of idioms regardless the language-user. Moreover, idioms can be ranked in terms of degrees of non-literalness in the same way as they can be ranked in terms of degrees of lexical fixity.

Palmer (1981: 81) says that idiomaticity can be a matter of degree and in the case of partial idioms; it can be little more than a matter of collocational restrictions. It is very difficult to decide whether a word or a sequence of words is opaque. Idioms may be defined in terms of non-equivalence in other languages, so that Kick the bucket, red herring, etc., are all idioms because they cannot be directly translated into French or German and giving the right meaning.

\section{Corpus Design \& Methodology}

Corpus design is required to be complemented by two further components to end up with a rather legitimate corpus-based research. These two components are based on: " (1) human intuition ( [sic] to interpret the data derived from corpora ..., (2) software tools to extract the data in the first place" (Anthony, 2009: 90). So, corpus designers should take a careful planning for making appropriate decisions that benefit them in identifying the texts included in the corpus (Kennedy, 1998: 71). Within every corpus, there is "language sample" (Leitner 1992, cited in Otlogetswe, 2011: 88). This sample might consist of written texts, such as books or spoken materials which build up the corpus (Otlogetswe, 2011: 88).

Additionally, complete texts like the Bible and full works of authors can also be included within a corpus (ibid). Finally, designing the corpus should be done by a clear-cut procedure so that the researcher can gain the "desired results" correctly (Vigier \& Sánchez, 2017: 262). In this regard, three different phases used in designing the corpus:

..., (1) documentation, in order to establish design criteria and search for original texts; (2) compilation, involving the downloading, logging and naming of original texts, their organization in folders, the conversion of formats and alignment to create bitext files; and (3) corpus analysis (Bolding mine) (ibid).

Therefore, the researcher adopts Vigier and Sanchez's procedures in designing his corpus. The corpus selected for this study mainly comprises on one dictionary, entitled Longman Idioms Dictionary. But why a dictionary? Well, choosing an idiomatic dictionary for comparing two varieties of a language seems more appropriate than having novels or other literary works as corpora. In this respect, Brook (1963: 146) says that studying language varieties through novels and the like is dependent on the novelist and his 
accuracy in reporting a certain language variety. Still, the evidence would be literary rather than linguistic. For this reason idiomatic dictionaries serve as the most accurate and native sources for exploring idioms.

\section{Models of Analysis}

The models that are going to be used in analysing idioms depend firstly on Halliday and Hasan's model. They (1985) analyse texts with reference to the cultural background of language-users. That is to say, a text, which is a form of language in actual use, makes the right sense according to all the surroundings of that text. Secondly, context of situation is now used as a specific term in Firthian Linguistic theory. In his theory, meaning comprises various facets being relatable, on the one hand, to features of the external world and to the different levels of linguistic analysis like phonetics, semantics, etc. on the other.

\section{Data Collection and Reliability of Data Source}

Data reliability is accomplished through authentic investigation. The researcher gained Longman Idioms Dictionary (LID) from the most authentic and reliable websites (i.e., www.Amazon.com).

\section{Data Processing via Word Smith Tools}

Doing a quantitative analysis, WordSmith Tools (henceforth WS) will analyze and compute the frequencies of 'British vs. American Idioms'. Knowing the essence of WS Tools, they operate on three major functions (e.g., Concordances, Wordlists and Keywords), (Zhang, 2014: 53). Hence, it is "developed by Mike Scott in 1996, predominantly for use by teachers and students in linguistics" (Easterby-Smith et al., 2012: 191). Thus, the researcher is going to use WS tools in his study to get the frequency of semantic change happened to occur in British and American idioms.

\section{Data Analysis \& Results}

Reaching at the core analysis of this study, this section is dedicated to reveal the main and most important semantic differences that distinguish between idioms in the two varieties, British and American; and how they realize, i.e. the semantic change, which takes place. The differentiation between British and American idioms is important, with a certain implication that it is, in many times, not possible to pick up an idiom and use it in Britain and/or America with the same meaning or connotation. Therefore, when scanning the Longman Idioms Dictionary, which provides an up-to-date account of idioms, and especially most frequently used ones, the researcher has aimed at collecting idioms with, at least, double meanings which are marked only British or only American. The investigation has yielded (31) idioms for both varieties and as shown in the following tables:

Table 1. Semantic Changes in British and American Idioms

\begin{tabular}{|l|l|l|}
\hline British Idioms & American Idioms & Total No. \\
\hline 16 & 15 & 31 \\
\hline
\end{tabular}


Table 2. British vs. American Idioms

\begin{tabular}{|c|c|}
\hline British Idioms & American Idioms \\
\hline 1. Do somebody proud & 1. In the hole. \\
\hline 2. Do me a favour & 2. Stack the cards. \\
\hline 3. Keep the flag flying & 3. Tie the knot. \\
\hline 4. Something opens & 4. Be full of beans \\
\hline floodgates & 5. Be tilting at windmills \\
\hline 5. Keep your head down & 6. Out of pocket \\
\hline 6. Go haywire & 7. At/ in a pinch \\
\hline 7. On the hoof & 8. Be a long shot. \\
\hline $\begin{array}{l}\text { 8. With an inch of your life } \\
\text { 9. The/ a melting pot }\end{array}$ & $\begin{array}{l}\text { 9. It takes all sorts/kinds (to make a } \\
\text { world). }\end{array}$ \\
\hline 10. Go off the rails & 10. Hand in glove \\
\hline 11. Make/ do a U turn & 11. Be nip and tuck \\
\hline 12. Blow hot and cold & 12. A close call \\
\hline 13. Be/look the worse to wear & 13. Draw a blank \\
\hline 14. Be caught short & 14. Push somebody's buttons. \\
\hline $\begin{array}{l}\text { 15. Be/ get hot under the collar } \\
\text { 16. Be in full flow/flood }\end{array}$ & 15. Bust a gut. \\
\hline
\end{tabular}

Before going deeply to the core analysis, one needs to know what the semantic change is in the first place. One of the preferences of semantic change is generating idioms that are used for avoiding offensive. That is, for example, instead of saying that someone is blind, one may politely say that someone is visually challenged. This is because such forms are widely used, and people make fun of them, as in the expressions:

- Vertically challenged. (= not very tall).

- Socially challenged. (= not very good at talking to people in social situations).

- $\quad$ Chronologically challenged. (= getting old).

Taking both the left and right columns into account, it seems that British idioms show that every certain period has its own appealing of social categories. This entails that language reflects the ideological changes of language-users and what is most preferred at a given period rather than the other. This might go behind the link between language and society, which is, in turn, a broken link especially in the present time due to the growth of the electronic information.

As for the prime concern in the present paper, it is the way in which idioms occur in specific situations. But why specific? This is because idioms are mainly institutionalised to occur with definite reference. Thus, it will be of importance to know how idioms are actually used in real life situations that distinguish between British and American English idioms, not to mention the know-how of interpreting idioms according to the situations in which they are unfold. See the following tables:

Table 3. Semantic Change of British Idioms

\begin{tabular}{|l|l|l|}
\hline British Idioms & Original Meaning & Mutual Idioms/ Semantic Change \\
\hline $\begin{array}{l}\text { Do somebody } \\
\text { proud }\end{array}$ & $\begin{array}{l}\text { To treat someone very well and } \\
\text { make them feel special. }\end{array}$ & $\begin{array}{l}\text { To make someone feel proud by doing something } \\
\text { well. }\end{array}$ \\
\hline Do me a favour & $\begin{array}{l}\text { Said when you do not believe } \\
\text { or agree with what someone } \\
\text { has said. }\end{array}$ & $\begin{array}{l}\text { Used when you are asking someone politely to } \\
\text { something for you. }\end{array}$ \\
\hline
\end{tabular}




\begin{tabular}{|c|c|c|}
\hline Keep the flag flying & $\begin{array}{l}\text { To achieve success for your } \\
\text { team, country etc. by playing } \\
\text { well in a sport. }\end{array}$ & $\begin{array}{l}\text { To continue to support an idea, follow a plan, etc., } \\
\text { especially when things become more difficult or the } \\
\text { idea or plan is not as popular as it once was. }\end{array}$ \\
\hline $\begin{array}{l}\text { Something opens } \\
\text { the floodgates }\end{array}$ & $\begin{array}{l}\text { To say that something makes } \\
\text { you express all of your } \\
\text { thoughts or feelings, especially } \\
\text { unhappy ones. }\end{array}$ & $\begin{array}{l}\text { To say that someone does something that had been } \\
\text { very difficult to do before, with the result that lots of } \\
\text { other people want to do it too. }\end{array}$ \\
\hline $\begin{array}{l}\text { Keep your head } \\
\text { down }\end{array}$ & $\begin{array}{l}\text { To think only about what you } \\
\text { are doing and ignore } \\
\text { everything else. }\end{array}$ & $\begin{array}{l}\text { To make sure that people do not notice you, for } \\
\text { example by doing your work and not causing any } \\
\text { problems. }\end{array}$ \\
\hline Go haywire & $\begin{array}{l}\text { To become very nervous or } \\
\text { excited. }\end{array}$ & $\begin{array}{l}\text { If a machine or process goes haywire, it stops } \\
\text { working properly and does strange and unexpected } \\
\text { thing. }\end{array}$ \\
\hline On the hoof & $\begin{array}{l}\text { If you make a decision or do } \\
\text { something on the hoof, you do } \\
\text { it quickly without planning, } \\
\text { because you must react to what } \\
\text { is happening at the time. }\end{array}$ & $\begin{array}{l}\text { If you do an activity on the hoof, you do it while you } \\
\text { are moving around or travelling to different places. }\end{array}$ \\
\hline $\begin{array}{l}\text { With an inch of } \\
\text { your life }\end{array}$ & $\begin{array}{l}\text { If you clean something to } \\
\text { within an inch of its life, you } \\
\text { rub it very hard while cleaning } \\
\text { it. }\end{array}$ & $\begin{array}{l}\text { If you beat someone to within an inch of their life, } \\
\text { you hit them hard many times so that they are badly } \\
\text { hurt. }\end{array}$ \\
\hline The/ a melting pot & $\begin{array}{l}\text { If a decision or the final result } \\
\text { of something is in the melting } \\
\text { pot, no one knows yet what it } \\
\text { will be. }\end{array}$ & $\begin{array}{l}\text { About a place where people form many different } \\
\text { countries come to live together and form one society, } \\
\text { or about an activity that is influenced by many } \\
\text { different styles or ideas. }\end{array}$ \\
\hline Go off the rails & $\begin{array}{l}\text { To start behaving } \\
\text { unbearable an } \\
\text { unacceptable way. }\end{array}$ & $\begin{array}{l}\text { If a system, organization, or process goes off the rails, } \\
\text { it starts to have problems and does not work or } \\
\text { develop as it should. }\end{array}$ \\
\hline Make/ do a U turn & $\begin{array}{l}\text { This idiom is used almost } \\
\text { always about politicians or } \\
\text { political parties who do the } \\
\text { opposite of what they have } \\
\text { promised to do. }\end{array}$ & Used about a complete change of ideas, plans. \\
\hline Blow hot and cold & $\begin{array}{l}\text { To sometimes perform well in } \\
\text { your work, and sometimes } \\
\text { perform badly. }\end{array}$ & $\begin{array}{l}\text { To keep changing your attitude about someone or } \\
\text { something, especially when you sometimes seem to } \\
\text { like them or be excited about them, and sometimes } \\
\text { seem the opposite. }\end{array}$ \\
\hline $\begin{array}{l}\text { Be/ look the worse } \\
\text { to wear }\end{array}$ & To be drunk. & $\begin{array}{l}\text { To say that something looks old and in bad condition, } \\
\text { or that someone looks tired and ill. }\end{array}$ \\
\hline Be caught short & $\begin{array}{l}\text { To not be near a toilet when } \\
\text { you need one. }\end{array}$ & $\begin{array}{l}\text { Be without something when you really need it, } \\
\text { especially money. }\end{array}$ \\
\hline $\begin{array}{l}\text { Be/ get hot under } \\
\text { the collar }\end{array}$ & $\begin{array}{l}\text { To be embarrassed because sex } \\
\text { is being talked about or you } \\
\text { have sexual feelings. }\end{array}$ & To be or become angry about something. \\
\hline $\begin{array}{l}\text { Be in full } \\
\text { flow/flood }\end{array}$ & $\begin{array}{l}\text { To be talking continually about } \\
\text { something and seem unlikely to } \\
\text { stop. }\end{array}$ & $\begin{array}{l}\text { If a process or activity is in full flow, it is happening } \\
\text { in a way that involves great energy or large numbers } \\
\text { of things or people. }\end{array}$ \\
\hline
\end{tabular}


Table 4. Semantic Change of American Idioms

\begin{tabular}{|c|c|c|}
\hline American Idioms & Original Meaning & $\begin{array}{l}\text { Mutual Meaning/ Semantic } \\
\text { Change }\end{array}$ \\
\hline In the hole & In debt. & In a bad situation. \\
\hline Stack the cards & $\begin{array}{l}\text { To arrange things unfairly for a } \\
\text { person. }\end{array}$ & $\begin{array}{l}\text { To arrange cards secretly and } \\
\text { dishonestly for the purpose of } \\
\text { cheating. }\end{array}$ \\
\hline Tie the knot & $\begin{array}{|lll|}\begin{array}{l}\text { To perform a wedding } \\
\text { ceremony. }\end{array} & \\
\end{array}$ & Get married. \\
\hline Be full of beans & $\begin{array}{l}\text { A slightly rude expression used } \\
\text { in order to tell someone that } \\
\text { you think his or her opinion is } \\
\text { wrong. }\end{array}$ & $\begin{array}{l}\text { To feel eager to do things and } \\
\text { have a lot of energy. }\end{array}$ \\
\hline Be tilting at windmills & $\begin{array}{l}\text { To try to solve a problem or } \\
\text { start work on a plan that seems } \\
\text { impossible to achieve. }\end{array}$ & $\begin{array}{l}\text { To say that someone wastes } \\
\text { time on ideas that are not } \\
\text { practical or important. }\end{array}$ \\
\hline Out of pocket & $\begin{array}{l}\text { If pay for something out of } \\
\text { pocket, you pay for it yourself } \\
\text { instead of getting the money } \\
\text { from someone else. }\end{array}$ & $\begin{array}{l}\text { To say that someone has lost } \\
\text { money because of a situation or } \\
\text { deal. }\end{array}$ \\
\hline At/in a pinch & $\begin{array}{l}\text { In a difficult or dangerous } \\
\text { situation. }\end{array}$ & $\begin{array}{l}\text { To say that something can be } \\
\text { done or used if necessary, } \\
\text { though it would not normally } \\
\text { be done or used. }\end{array}$ \\
\hline Be a long shot & $\begin{array}{l}\text { If someone is a long shot they } \\
\text { are not likely to be chosen for a } \\
\text { job or win an election, } \\
\text { competition, etc. }\end{array}$ & $\begin{array}{l}\text { Used in order to say that a plan } \\
\text { is worth trying even though you } \\
\text { think it is not likely to succeed. }\end{array}$ \\
\hline $\begin{array}{l}\text { It takes all sorts/kinds (to make } \\
\text { a world). }\end{array}$ & To feel ill or upset. & $\begin{array}{l}\text { To say that everyone is } \\
\text { different, and often used } \\
\text { humorously when you think } \\
\text { that what someone else is } \\
\text { doing, likes etc. is strange. }\end{array}$ \\
\hline Hand in glove & $\begin{array}{l}\text { Used in order to say that two } \\
\text { things are very suitable for each } \\
\text { other, or work very well } \\
\text { together. }\end{array}$ & $\begin{array}{l}\text { To emphasize that someone is } \\
\text { closely involved with someone } \\
\text { else, especially in a bad or } \\
\text { illegal activity. }\end{array}$ \\
\hline Be nip and tuck & $\begin{array}{l}\text { To say that you very nearly did } \\
\text { not finish something or arrive } \\
\text { somewhere on time. }\end{array}$ & $\begin{array}{l}\text { To say that people or teams are } \\
\text { doing equally well in a } \\
\text { competition, so that it is } \\
\text { difficult to know who will win }\end{array}$ \\
\hline A close call & $\begin{array}{l}\text { A situation in which it is } \\
\text { difficult to know which of the } \\
\text { choices to make, or which of the } \\
\text { two things is likely to happen. }\end{array}$ & $\begin{array}{l}\text { A situation in which you were } \\
\text { nearly hurt or killed, or in } \\
\text { which something bad nearly } \\
\text { happened to you. }\end{array}$ \\
\hline Draw a blank & $\begin{array}{l}\text { To be unable to answer a } \\
\text { question, or unwilling to give } \\
\text { information. }\end{array}$ & $\begin{array}{l}\text { To fail to get the information } \\
\text { that you want, or fail to find the } \\
\text { thing or person that you are } \\
\text { looking for. }\end{array}$ \\
\hline Push somebody's buttons & $\begin{array}{l}\text { To annoy someone, sometimes } \\
\text { when you do not intend to, by } \\
\text { doing a lot of things that they } \\
\text { do not like. }\end{array}$ & $\begin{array}{l}\text { To know exactly what to do or } \\
\text { say in order to get the reaction } \\
\text { or result that you want. }\end{array}$ \\
\hline
\end{tabular}




\begin{tabular}{|l|l|l|}
\hline Bust a gut & To laugh a lot & $\begin{array}{l}\text { To work very hard in order to } \\
\text { finish or achieve something. }\end{array}$ \\
\hline
\end{tabular}

What is more, it can be observed here, that British idioms are experiencing more semantic change than American ones. Such a change shows that British English depends more on keeping the idiom but with using it in other situations, rather than adopting new coinages of idioms, which seems to be a characteristic of American English.

Having in mind the idea that an idiom might hold a double meaning (See Tables $3 \& 4$ ), it then can be noted that this idiom is used in at least two situations. The situation, here, is an intrinsic element in distinguishing between the two meanings of the idiom. These situational differences are present between the British and American idioms, at the mutual part. Hence, mutual idioms are those shared by the two varieties but with special usages that are developed over the passage of time (i.e., having semantic changes).

Going to dig up a further investigation, it is time to deal with the data gathered quantitatively via WS tools for the sake of reaching at the most accurate and reliable results. Such an analysis is done through the use of Type/Token Ratio (TTR) specified in WS tools.

Table 5. The Frequencies of Semantic Change of British \& American Idioms

\begin{tabular}{|l|l|}
\hline British Idioms/ TTR for 16 idioms & American Idioms/ TTR for 15 idoms \\
\hline $33 \%$ & $22 \%$ \\
$31 \%$ & $25 \%$ \\
$32 \%$ & $22 \%$ \\
$29 \%$ & $24 \%$ \\
$29 \%$ & $25 \%$ \\
$27 \%$ & $13 \%$ \\
$27 \%$ & $11 \%$ \\
$28 \%$ & $12 \%$ \\
$26 \%$ & $17 \%$ \\
$13 \%$ & $13 \%$ \\
$21 \%$ & $10 \%$ \\
$15 \%$ & $24 \%$ \\
$22 \%$ & $27 \%$ \\
$25 \%$ & $9 \%$ \\
$29 \%$ & $17 \%$ \\
$24 \%$ & \\
\hline
\end{tabular}




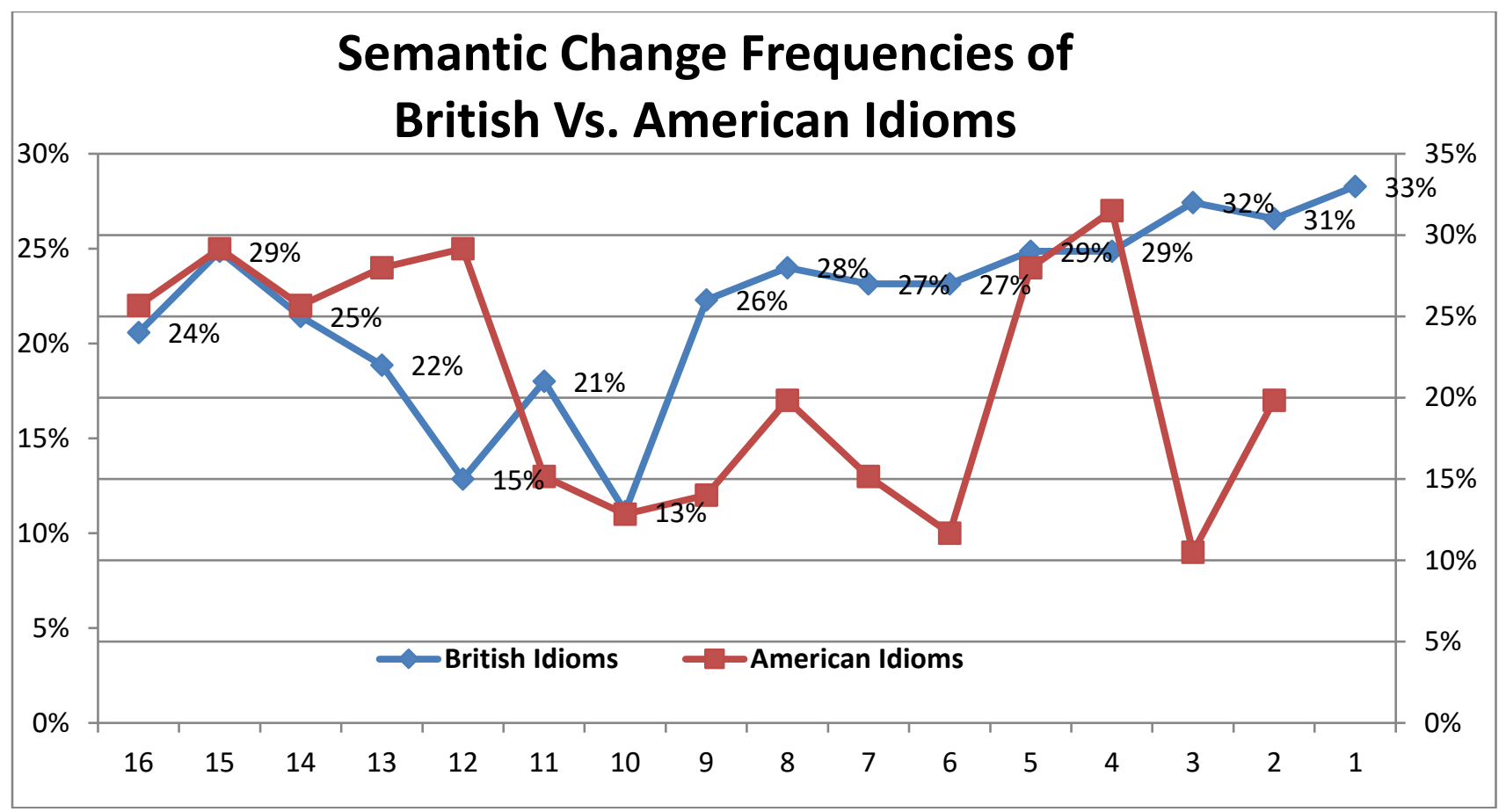

Figure 1. Semantic Change Frequencies of British \& American Idioms

Following the table and its visualized curves plotted above, idioms in British and American English have revealed situational differences. Not accounting for these differences is likely to cause miscommunication. To know how to discriminate between idioms in both varieties of English, one should mainly appeal to contextual considerations whether being verbal or physical. These situational variations result in semantic variations.

What triggers the change of an idiom is the repeated use of that idiom in other contexts. It has been found that British idioms, on the one hand, scored the highest degree of semantic change. This goes behind the fact that they show a certain tendency of linguistic conservatism by keeping the form and changing the idiomatic meaning, though it is also evident that some British idioms change in form and preserve the idiomatic meaning.

As for American idioms, they scored the lowest degree of semantic change. But, some idiomatic expressions of the two varieties of English are met together to some extent (see the idioms No. 10, 11, 14 \& 15 plotted above). This indicates that such idioms also reflect a certain tendency of British English to generate idioms. American idioms are in fact more idiomatic in that many topics can be traced when dealing with British idioms. It is evident, in American English, that two or more idioms denote the same idea, and hence are generated and spread faster than British idioms.

\section{CONCLUSIONS}

Rounding off this study, the researcher has come across the following conclusions:

1. American English is more idiomatic in that many topics can be traced when dealing with American idioms. These idioms are generated and spread faster than British idioms. It is evident in American English that two or more idioms denote the same idea.

2. British idioms reflect the tendency of relying on historical motivation and dependence on written texts. Many of these idioms are also found in American English due to language inheritance and the previous influence of the British Empire. On the other hand, American idioms reflect a certain tendency of American English to generate idioms from the domains of politics, sports and technology and a heavy dependence on the role of the media, which also show a certain turning point for the generation of idioms. 
3. Americans are freer than the British in using and developing their variety of language. Examples for this point are the rapid generation and use of idioms in addition to the use of contractions by which idioms, in many times, are shortened and compounded to be used as adjectives or adverbs.

4. Noting the conventionality and overuse of an idiomatic expression, it is evident that language-users usually bypass the metaphorical reference in the idiom; that is to say, the metaphor may no longer be important since the sequence of words in question have acquired the intended denotation.

5. The criterion of non-literalness of idioms is mainly the result of the figurative extension, i.e. when the sequence of words denoting a certain situation of everyday life is figuratively extended by languageusers, into another situation that has certain similarities with the original situation.

6. Idioms are not necessarily illogical or absurd. These idioms reflect logical associations between two situations.

7. Idioms are not confined to a certain structure, but any sequence of words or a single word, denoting a certain idea or situation can be used idiomatically. Still, idioms are usually short and easily memorized expressions. They normally resist change, but when they change, they reflect certain cultural reasons that result in such a change. The modification of idioms is usually a semantic one since the form is, at a large scale, kept as it is.

\section{REFERENCES}

Alber, D. (2013). English Idioms: An Idiomatic Journey to the West. United States: Easy American Accent.

Anthony, L. ( 2009 ) . "Issues in the Design and the Development of Software Tools for Corpus Studies: The Case for Collaboration". In Baker, P. (ed.) 2009. Contemporary Corpus Linguistics. London: Continuum International Publishing Group.

Baugh, A. C. (1957). A History of the English language. London: Routledge and Kegan Paul Ltd.

Brook, G. L. (1958). A History of The English Language. London: Andre Deutsch Ltd.

Brook, G. L. (1963). English Dialects. London: Andre Deutsch.

Clark, H. H. and E. V. Clark.

(1977). Psychology and Language: An Introduction to Psycholinguistics. New York: Harcourt Brace Jovanovich.

Cowie, A. P., R. Mackin and I. R. McCaig. (1983). Oxford Dictionary of Current Idiomatic English. Vol.2. Oxford: Oxford University Press.

Crystal, D. (2019). The Cambridge Encyclopedia of the English Language. Cambridge: Cambridge University Press.

Easterby-Smith, M., Thorpe, R. \& Jackson, P. (2012). Management Research (4th ed.). London: Sage Publishing. Retrieved 3 December 2020.

Fernando, C. (1996). Idioms and Idiomaticity. Oxford: Oxford University Press.

Fernando, C. and R. Flavell. (1981). On Idiom. Exeter: University of Exeter.

Firth, J. R. (1950). 'Personality and Language in Society'. Sociological Review. No. xlii, pp. 37-52. Reprinted in Firth (1957a), pp. 177-89.

Fromkin, V. and R. Rodman. (1988). An Introduction to Language(4th ed.). Chicago: Holt, Rinehart and Winston, Inc.

Halliday, M. A. K. and R. Hasan, (1985). Language, Context, and Text: Aspects of Language in a Social-Semiotic Perspective. Victoria: Deakin University Press.

Kennedy, G. (1998). An Introduction to Corpus Linguistics. London \& New York: Routledge Books Retrieved from https://books.google.iq/ (1 Feb 2021).

Longman Idioms Dictionary (1998). Essex: Addison Wesley Longman Ltd.

Makkai, A. (1975). A Dictionary of American Idioms. New York: Barron's Educational Series, Inc.

Otlogetswe, T. (2011). Text Variability Measure in Corpus Design for Setswana Lexicography. London: Cambridge Scholars Publishing. Retrieved from http://www.cambridgescholars.com/ (2 Feb. 2021).

Palmer, F.R. (1981). Semantics. Cambridge. Cambridge University Press.

Scott, M. (2015). WordSmith Tools Manual (ver.6.0). UK: Lexical Analysis Software Ltd.

Vigier, F. \& Sánchez, M. (2017). "Using Parallel Corpora to Study the Translation of Legal System-Bound Terms: The Case of Names of English and Spanish Courts". In Mitkov, R. (ed.) 2017. Computational and Corpus-Based Phraseology: Second International Conference, Europhras 2017, London, UK, November 1314, 2017, Proceedings. Switzerland: Springer. 
Whitford, H. C. and R. J. Dixon. (1973). Handbook of American Idioms and Idiomatic Usage. New York: Regents Publishing Co. Inc.

Zerfas, A. (2014). Death Idioms in the English and German language: A Contrastive Analysis. Berlin: Grin Verlag. Zhang, R. (2014). Sadness Expressions in English and Chinese: Corpus Linguistic Contrastive Semantic Analysis. London: Bloomsbury Academic Publishing Plc. 